\title{
Sustainable Textile School Goes to the World Textile Forum in Zürich
}

\author{
Sonja Amport* \\ Swiss Textile School STF, Switzerland
}

*Corresponding author: Sonja Amport, Director Swiss Textile School STF, Zurich, Canton of Zurich, Switzerland.

Received Date: May 23, 2019

Published Date: May 28, 2019

\section{Opinion}

In 2018 the "Sustainable Textile School" took 130 participants from 38 countries to Chemnitz, and in 2019, this intensive exchange on sustainability and digitalization is taking place at the World Textile Forum in Zürich, just before the Global Fibre Congress in Dornbirn in September.

To enable a scientifically-sound exchange of knowledge on sustainability all along the supply chain, the "Sustainable Textile School" began in Chemnitz in 2017 with leading textiles companies and participants from 30 countries. This year we're delighted to be merging with the World Textile Forum in Zürich to tackle the topic of sustainability and digitalization.

\section{Quick start in 2017}

The first edition of the international Sustainable Textile School (STS) in Chemnitz was organized by Gherzi Textile Organization (www.gherzi.com), together with the Chemnitz University of Technology (www.tu-chemnitz.de), EURATEX (www.euratex. eu), and the sponsors Rudolf Chemie (www.rudolf.de), Li \& Fung Germany (www.milesgroup.eu), the Südwolle Group (www. suedwollegroup.com) and other partners.

The aim of the conference was and is to develop a sciencebased exchange of knowledge regarding sustainable production and sustainable business models for the production stages of the supply chain in the industry. More than 80 participants from 30 countries were delighted by the enthusiastic and fruitful discourse between training providers and companies around pressing topics in the textiles industry.

Under the heading "Sustainable is the new quality!", the topic of sustainability was designed and developed by STS to be a topic for product developers, engineers, and supply chain managers, not just one for the communications department.

\section{Digital sourcing \& production}

The network of 16 international universities and 46 companies with 130 participants from 38 countries developed further thanks to the second STS in Chemnitz in 2018. Process optimization and waste management in the textiles chain were the dominant topics in the talks and breakout sessions. The topic of digitalization, and thus "Digital Sourcing \& Production", was chosen as the key topic for the 2019 event.

\section{How to make business in the future?}

In 2019, we're starting again as the WORLD TEXTILE FORUM in Zürich. Thanks to close collaboration with the Swiss Textile Federation (www.swisstextiles.ch), the STF (Swiss textile technical school - schweizerische Textile fachschule, www.stf.ch) and EURATEX (www.euratex.eu), on 9 and 10 September together with international participants, the megatrends of digitalization and sustainability will be pragmatically linked together for the textiles industry so we can deal with the question of "how to make business in the future?" (Giuseppe Gherzi). The event in Zürich is aimed at decision-makers, developers, innovators, and the driving forces in the international textiles chain who have understood that the industry will continue changing dramatically in the coming years.

Thanks to international regulations, sustainability is becoming more and more of something companies must have than something it's nice for them to have, as digitalization facilitates innovative and fast communication channels to customers in a world-wide network of platform and production capacities. 


\section{Acknowledgement}

None.

\section{Conflict of Interest}

No conflict of interest. 